\title{
PENGARUH PENGGUNAAN MEDIA FILM PENDEK KARYA EKA GUSTIWANA TERHADAP KEMAMPUAN MENULIS PUISI SISWA KELAS X SMA FREE METHODODIST MEDAN TAHUN PEMBELAJARAN 2017/2018
}

\author{
Glory Caterine Simangunsong \\ (email: glorycaterines) \\ Drs. Azhar Umar, M.Pd
}

\begin{abstract}
ABSTRAK
Penelitian ini bertujuan untuk mengetahui apakah penggunaan media film pendek karya Eka Gustiwanadapat meningkatkan kemampuan menulis puisi siswa kelas X SMA Free Methodist Medan. Populasi penelitian ini adalah seluruh siswa kelas X SMA Free Methodist Medan Tahun Pembelajaran 2017/2018 yang berjumlah 120 orang. Sampel pada penelitian ini adalah kelas X MIA yang terdiri dari 30siswa. Metode penelitian yang digunakan yaitu eksperimen dengan one-group pretest-postest design. Instrumen yang digunakan yaitu siswa ditugaskan menulis puisi. Tes ini akan diberlakukan untuk Pre test dan post test. Pre test digunakan untuk menjaring data dalam kemampuan menulis puisi sebelum diadakan perlakuan, sedangkan post test digunakan untuk menjaring data dalam kemampuan menulis puisi setelah diadakan perlakuan dengan menggunakan media film pendek.

Hasil penelitian menunjukkan adanya peningkatan kemampuan menulis puisi siswa kelas X SMA Free Methodist Medan sesudah menggunakan media film pendek. Pada test awal, kemampuan menulis puisi siswa kelas X SMA Free Methodist Medan tergolong pada kategori cukup dengan nilai 64,5. Pada tes akhir, yaitu menggunakan media film pendek karya Eka Gustiwana, kemampuan menulis puisi siswa kelas X SMA Free Methodist Medan tergolong pada kategori baik dengan nilai 83,16. . Kemudian pengujian hipotesis yang dilakukan diperoleh $t_{0}>t_{\text {tabel}}$, yaitu 9,692>2.04.Maka, hipotesis alternatif (Ha) diterima. Dengan demikian penggunaan media film pendek karya Eka Gustiwana ini berpengaruh secara signifikan terhadap kemampuan menulis puisi siswa kelas X SMA Free Methodist Medan Tahun Pembelajaran 2017/2018.
\end{abstract}

Kata Kunci: Media, Fim Pendek, Menulis Puisi

\section{PENDAHULUAN}

Pembelajaran bahasa Indonesia merupakan salah satu mata pelajaran terpenting di sekolah.Salah satu fokus pembelajaran ini adalah memusatkan agar terwujudnya keterampilan berbahasa.Di antara keempat keterampilan berbahasa tersebut, menulis merupakan keterampilan berbahasa paling akhir dikuasai seseorang setelah keterampilan 
menyimak, berbicara, dan membaca. Dibanding tiga keterampilan berbahasa yang lain, keterampilan menulis lebih sulit dikuasai oleh penutur bahasa. Hal ini disebabkan adanya dua unsur yang harus dikuasai oleh penulis, yaitu unsur bahasa seperti ejaan, tanda baca, koherensi, kohesi dan non bahasa seperti ide atau gagasaan dalam sebuah tulisan yang meliputi pengalaman dan pengetahuan penulis. Menurut Tarigan (2008 : 3) menulis merupakan suatu keterampilan berbahasa yang dipergunakan untuk komunikasi secara tidak langsung dan secara tidak tatap muka.

Kemampuan menulis, khususnya menulis puisi yang sesuai dengan Kurikulum 2013 edisi Revisi 2016 merupakan kompetensi dasar yang harus dicapai siswa. Hal tersebut terdapat pada KD 4.17 yaitu menulis puisi dengan memerhatikan unsur pembangunnya.Dalam pembelajaran menulis puisi, banyak ditemukan beberapa masalah yang menyebabkan kemampuan menulis puisi siswa belum maksimal. Suhatman Jaya dalam jurnal penelitiannya yang berjudul "Peningkatan Keterampilan Menulis Puisi Melalui Media Gambar Siswa Kelas X.1 SMA Negeri 2 Kota Sungai Penuh"mengatakan masih rendahnya keterampilan siswa dalam menulis puisi. Setelah diadakan pengamatan terhadap siswa kelas X.1 SMA Negeri 2 Kota Sungai Penuh pada semester ganjil tahun pelajaran 2010/2011, SK 8, KD 8.2 siswa yang memperoleh nilai sama atau di atas KKM hanya $45 \%$ dari yang telah ditetapkan sekolah yaitu 70 .

Salah satu masalah tersebut adalah kemampuan menulis puisi siswa masih tergolong rendah. Rendahnya kemampuan menulis puisi siswa disebabkan (1) tidak tepatnya penggunaan bahasa dan diksi yang puitis, (2) puisi yang ditulis siswa cenderung bersifat informasional sehingga kurang dapat membangkitkan emosional pembaca, (3) Siswa belum mampu menggunakan kata-kata yang tepat, sehingga tidak menimbulkan bunyi yang merdu yang mendukung efek kepuitisan sebuah puisi. Masalah lain yang timbul dalam pembelajaran menulis puisi adalah siswa masih sulit mengungkapakan ide atau gagasan ke dalam sebuah puisi.

Berdasarkan beberapa faktor dia tersebut, penggunaan media pembelajaran merupakan salah satu solusi dari permasalahan dalam pembelajaran menulis. Hamalik (1986) menyatakan pemakaian media pembelajaran dalam proses belajar mengajar dapat meningkatkan keinginan dan minat yang baru, membangkitkan motivasi dan rangsangan kegiatan belajar dan bahkan membawa pengaruh-pengaruh psikologis terhadap siswa. Salah satu solusi yang dapat ditawarkan dalam pembelajaran menulis puisi adalah dengan menggunakan media proyeksi berupa film. Media film akan lebih menarik karena tidak hanya 
menampilkan pesan gambar (visual), tetapi juga disertai pesan suara (audio). Selain itu, film juga mampu melibatkan perasaan penontonnya sehingga pesan yang disampaikan lebih mudah untuk dipahami.

Penelitian dengan menggunakan media film pendek juga telah dilakukan diantaranya oleh Rizki Merlyn Palopi dkk (2012) yang berjudul "Film Pendek sebagai Media untuk Meningkatkan Pembelajaran Menulis Cerpen berdasarkan Pengalaman Orang Lain Oleh Siswa Kelas X-4 SMAN 2 Batu" menyatakan bahwa terjadi peningkatan aktivitas belajar siswa kelas X-4 setelah diterapkannya pembelajaran menulis cerpen dengan media film pendek. Hal ini dapat dilihat dari nilai rata-rata siswa sebelum diterapkan tindakan dalam menulis cerpen dalah 65. Pada siklus I mengalami peningkatan rata-rata hasil belajar siswa menulis cerpen menjadi 73 pada kategori cukup baik. Sedangkan pada siklus II meningkat menjadi 83,3 pada kualifikasi baik.

Film yang dipilih sebagai media dalam pembelajaran menulis puisi ini adalah film pendek. Media film pendek yang digunakan berupa film pendek yang diambil dari salah satu chanel Youtube milik Eka Gustiwana yang bertemakan Ibu. Media film pendek karya Eka Gustiwana ini menampilkan perjuangan dan kasih sayang seorang ibu kepada anaknya. Media film pendek karya Eka Gustiwana mengandung pesan, kritik, dan informasi yang dapat merangsang siswa untuk mengungkapkan ide, gagasan, dan pikirannya. Penggunaan media film pendek karya Eka Gustiwana dalam pembelajaran menulis puisi diharapkan dapat memudahkan siswa dalam menyampaikan ide, gagasan serta perasaannya ke dalam bentuk puisi. Penggunaan media ini juga merupakan upaya untuk menciptakan suasana baru dalam pembelajaran menulis puisi, khususnya untuk siswa kelas X SMA Free Methodist Medan.

\section{METODE PENELITIAN}

Metode penelitian yang digunakan yaitu eksperimen dengan one-group pretest-postest design. Penelitian ini dilakukan untuk mengetahui pengaruh media film pendek karya Eka Gustiwana terhadap kemampuan menulis puisi siswa kelas X SMA Free Methodist Medan. . Desain penelitian akan membantu penulis selama melakukan penelitian. Desain eksperimen pada penelitian ini menggunkan pre-experimental design dengan bentuk one group pretestposttest design. Desain penelitian dengan one group pretest-posttest design adalah desain eksperimen yang dilaksankan pada satu kelompok saja tanpa kelompok pembanding (Arikunto, 2006:212). Dalam desain ini penulis menggunakan tes menulis puisi sebanyak dua kali, yaitu tes awal untuk mengetahui kemampuan menulis puisi sebelum menggunakan 
media film pendek karya Eka Gustiwana dan tes akhir untuk mengetahui kemampuan menulis puisi sesudah menggunakan media film pendek karya Eka Gustiwana.

Instrumen yang digunakan yaitu siswa ditugaskan menulis puisi. Tes ini akan diberlakukan untuk Pre test dan post test. Pre test digunakan untuk menjaring data dalam kemampuan menulis puisi sebelum diadakan perlakuan, sedangkan post test digunakan untuk menjaring data dalam kemampuan menulis puisi setelah diadakan perlakuan dengan menggunakan media film pendek.

Indikator yang digunakan dalam menulis puisi telah dijelaskan sebelumnya yakni pada aspek penilaian kemampuan menulis puisi. Waluyo (1987:101), mengemukakan bahwasanya yang dijadikan pedoman untuk menulis puisi berdasarkan unsur-unsur puisi berupa tema, amanat, diksi (pemilihan kata), gaya bahasa, dan rima yang diuraikan dalam tabel berikut.

Tabel 1. Aspek Penilaian Kemampuan Menulis Puisi

\begin{tabular}{|c|c|c|c|c|c|}
\hline No & $\begin{array}{c}\text { Aspek } \\
\text { yang } \\
\text { dinilai } \\
\end{array}$ & $\begin{array}{c}\text { Kriteria } \\
\text { penilaian }\end{array}$ & Indikator & Skor & $\begin{array}{l}\text { Total } \\
\text { Skor }\end{array}$ \\
\hline 1 & Tema & $\begin{array}{l}\text { Kesesuaian isi } \\
\text { puisi dengan } \\
\text { judul dan tema }\end{array}$ & $\begin{array}{l}\text { Sangat Baik: isi sangat sesuai } \\
\text { dengan tema yang ditentukan-isi } \\
\text { sangat sesuai dengan judul puisi- } \\
\text { pemilihan judul kreatif } \\
\text { Baik: isi sesuai dengan tema yang } \\
\text { ditentukan-isi sesuai dengan } \\
\text { judul puisi-judul kurang kreatif } \\
\text { Cukup Baik: isi puisi kurang } \\
\text { relevan dengan tema yang } \\
\text { ditentukan-isi puisi kurang sesuai } \\
\text { dengan judul puisi-judul kurang } \\
\text { kreatif } \\
\text { Kurang Baik: isi tidak relevan } \\
\text { dengan tema dan judul puisi } \\
\text { sesuai dengan tema }\end{array}$ & 10 & 20 \\
\hline 2 & Amanat & $\begin{array}{l}\text { Penyampaian } \\
\text { amanat }\end{array}$ & $\begin{array}{l}\text { Sangat Baik: adanya } \\
\text { penyampaian amanat jelas-dapat } \\
\text { dimengerti. } \\
\text { Baik: adanya penyampaian } \\
\text { amanat-kurang jelas, kurang } \\
\text { dapat dimengerti. } \\
\text { Cukup Baik: adanya } \\
\text { penyampaian amanat tidak }\end{array}$ & $\begin{array}{l}15 \\
10\end{array}$ & 20 \\
\hline
\end{tabular}




\begin{tabular}{|c|c|c|c|c|c|}
\hline & & & $\begin{array}{l}\text { jelas-tidak dapat dimengerti. } \\
\text { Kurang Baik: tidak ada } \\
\text { penyampaian amanat baik tersirat } \\
\text { maupun tersurat. }\end{array}$ & 5 & \\
\hline 3 & $\begin{array}{l}\text { Diksi } \\
\text { (Pilihan } \\
\text { kata) }\end{array}$ & $\begin{array}{l}\text { Pemilihan kata } \\
\text { yang dipakai }\end{array}$ & $\begin{array}{l}\text { Sangat Baik: pemilihan kata } \\
\text { tepat-tidak bersifat keseharian- } \\
\text { penggunaan kata efektif bahasa } \\
\text { padat. } \\
\text { Baik: pemilihan kata tepat-tidak } \\
\text { bersifat keseharian- penggunaan } \\
\text { kata efektif-bahasa } \\
\text { kurang padat. } \\
\text { Cukup Baik: pemilihan kata } \\
\text { tepat-bersifat keseharian } \\
\text { penggunaan kata efektif-bahasa } \\
\text { padat. } \\
\text { Kurang Baik: pemilihan kata } \\
\text { kurang tepat bersifat keseharian- } \\
\text { penggunaan kata kurang efektif- } \\
\text { bahasa kurang padat.pat dan } \\
\text { kurang memiliki keindahan } \\
\text { (estetis) }\end{array}$ & 10 & 20 \\
\hline 4 & $\begin{array}{l}\text { Gaya } \\
\text { bahasa }\end{array}$ & $\begin{array}{l}\text { Penggunaan } \\
\text { Bahasa Kias }\end{array}$ & $\begin{array}{l}\text { Sangat Baik: penggunaan } \\
\text { minimal } 3 \text { variasi bahasa kias } \\
\text { yaitu hiperbola, personifikasi dan } \\
\text { metafora-tepat-estetis-sangat } \\
\text { mengekspresikan. } \\
\text { Baik: penggunaan } 2 \text { variasi } \\
\text { bahasa kias-tepat-estetis- } \\
\text { mengekspresikan pikiran yang } \\
\text { diungkapkan. } \\
\text { Cukup Baik: penggunaan } 1 \\
\text { variasi bahasa kias-tepat-estetis- } \\
\text { cukup mengekspresikan pikiran } \\
\text { yang diungkapkan dalam puisi } \\
\text { Kurang Baik: tidak menggunakan } \\
\text { bahasa kias. }\end{array}$ & $\begin{array}{l}15 \\
10\end{array}$ & 20 \\
\hline 5 & Rima & Kesesuaian rima & $\begin{array}{l}\text { Sangat Baik: adanya penggunaan } \\
\text { minimal } 3 \text { variasi rima- } \\
\text { memunculkan irama yang sangat } \\
\text { menarik dalam puisi. }\end{array}$ & $\begin{array}{l}20 \\
15\end{array}$ & 20 \\
\hline
\end{tabular}




\begin{tabular}{|l|l|l|c|c|}
\hline & $\begin{array}{l}\text { Baik: adanya penggunaan 2 } \\
\text { variasi rima menimbulkan irama } \\
\text { yang menarik dalam puisi. } \\
\text { Cukup Baik: adanya penggunaan } \\
1 \text { variasi rima- cukup } \\
\text { menimbulkan irama dalam puisi. } \\
\text { Kurang Baik: tidak menggunakan } \\
\text { variasi rima. }\end{array}$ & 5 & 10 \\
\hline
\end{tabular}

(Waluyo, 1987: 101)

Data yang diperoleh dari lapangan adalah data yang belum diolah.Data tersebut perlu diolah agar hipotesis dapat dibuktikan. Pengolahan data akan menghasilkan kesimpulan yang valid tentang masalah yang diteliti.

Teknik analisis data dapat dilakukan dengan langkah sebagai berikut.

1.Menyusun data pre-test dan post-test dalam bentuk tabel.

2.Menghitung nilai rata-rata skor dari variabel pre-test dan post-test dengan menggunakan rumus :

$$
\mathrm{M}_{\mathrm{x}}=\left[\frac{\sum f X}{N}\right]
$$

Keterangan :

$$
\begin{array}{ll}
\mathrm{M}_{\mathrm{x}} & =\text { Rata-rata (Mean) } \\
\sum \mathrm{fx} & =\text { jumlah perkalian frekuensi dengan variabel } \mathrm{x} \\
\mathrm{N} & =\text { jumlah sampel }
\end{array}
$$

3.Menghitung standar deviasi dari variabel hasil pre-test dan post-test dengan menggunakan rumus:

$$
\mathrm{SD}=\sqrt{\frac{\sum f x^{2}}{N}}
$$

Keterangan :

$$
\begin{aligned}
& \mathrm{SD}=\text { Standar Deviasi } \\
& \mathrm{N}=\text { Jumlah sampel } \\
& \sum \mathrm{fx}^{2}=\text { Kuadrat jumlah perkalian frekuensi dengan variabel } \mathrm{x}
\end{aligned}
$$




\section{HASIL PENELITIAN}

\section{Kemampuan Menulis Puisi Siswa Sebelum Menggunakan Media Film Pendek Karya Eka Gustiwana}

Berdasarkan nilai kemampuan menulis puisi sebelum menggunakan media film pendek karya Eka Gustiwana diperoleh nilai terendah 55 dan nilai tertinggi 75. Nilai rata-rata pada setiap aspek adalah aspek tema yaitu 20, pada aspek amanat adalah19,66. Rata-rata pada aspek diksi adalah 9,33. Rata-rata pada aspek gaya bahasa adalah 7,5. Rata-rata pada aspek rima adalah 8.Kemudian rata-rata akumulasi nilai keseluruhan adalah 64.5.

Hasil penelitian dari pre-test tersebut menunjukkan bahwa kemampuan menulis puisi siswa masih tergolong rendah. Hal ini bukanlah yang diharapkan dari proses kegiatan belajar di sekolah. Rendahnya kemampuan menulis siswa ini disebabkan oleh siswa yang masih terpaku pada apa yang diberikan oleh guru saja yang membuat mereka merasa bosan dan tidak memiliki minat dalam belajar serta motivasi dalam menulis puisi.

Berdasarkan tabel di atas, maka dapat diketahui bahwa kemampuan menulis puisi siswa sebelum menggunakan media film pendek karya Eka Gustiwana terbagi atas kategori Baik sebanyak 11 siswa atau 36,66 \%, kategori cukup sebanyak 14 siswa atau 46,66\%, kategori kurang sebanyak 5 siswa atau $16,66 \%$.

\section{Kemampuan Menulis Puisi Siswa Sesudah Menggunakan Media Film Pendek Karya Eka Gustiwana}

Berdasarkan nilai kemampuan menulis puisi setelah menggunakan media film pendek karya Eka Gustiwana diperoleh nilai terendah 65 dan nilai tertinggi 95. Nilai rata-rata pada setiap aspek adalah, aspek tema dan amanat adalah 20. Rata-rata pada aspek diksi adalah 16,16. Rata-rata pada aspek gaya bahasa adalah 14,66 . Rata-rata pada aspek rima adalah 11,53. Kemudian rata-rata akumulasi nilai keseluruhan adalah 83.16.

Hasil penelitian dari post-test tersebut menunjukkan bahwa kemampuan menulis puisi siswa meningkat setelah menggunakan media film pendek karya Eka Gustiwana. Artinya media film pendek karya Eka Gustiwana berpengaruh terhadap peningkatan kemampuan menulis puisi siswa. Media Film Pendek Karya Eka Gustiwana menuntun siswa dalam menulis puisi dengan alur yang menarik, sehingga siswa termotivasi, tertarik, serta mudah menuangkan idenya dalam menulis puisi. 
Berdasarkan tabel di atas, maka dapat diketahui bahwa kemampuan menulis puisi oleh siswa setelah menggunakan media film pendek karya Eka Gustiwana terbagi atas kategori Sangat Baik sebanyak 19 siswa atau 63,33\% \%, kategori baik sebanyak 9 siswa atau $30 \%$, dan kategori cukup sebanyak 2 siswa atau $6,66 \%$.

\section{PEMBAHASAN HASIL PENELITIAN}

\section{Kemampuan Menulis Puisi Siswa Kelas X SMA Free Methodist Medan Sebelum Menggunakan Media Film Pendek Karya Eka Gustiwana}

Hasil menulis puisi siswa kelas X SMA Free Methodist Medan Tahun Pembelajaran 2017/2018 sebelum menggunakan media film pendek, termasuk dalam kategori cukup dengan nilai rata-rata 64,5. Kemampuan ini berada di bawah KKM yang sudah ditetapkan SMA Free Methodist yaitu sebesar 75.

Sebagaimana disajikan pada hasil penelitian, bahwasanya hal ini sesuai dengan penelitian yang dilakukan oleh Rian Dana Abidin (2014).Menyatakan bahwa dari jumlah keseluruhan 33 siswa, tidak ada satu pun siswa atau 0\% yang meraih kategori istimewa yaitu dengan nilai 10.Tidak ada satu pun siswa atau $0 \%$ meraih kategori baik sekali dengan nilai 9.Tidak ada satu pun siswa atau 0\% meraih kategori baik dengan nilai 8 . Sebanyak 3 orang siswa atau 9,10\% yang memperoleh kategori lebih dari cukup yaitu dengan nilai 7, sebanyak 10 orang siswa atau 30,30\% meraih kategori cukup yaitu dengan nilai 6 , sebanyak 14 orang siswa atau $42,42 \%$ meraih kategori hampir cukup dengan nilai 5. Sebanyak 6 orang siswa atau 18,18\% meraih kategori kurang yaitu dengan nilai 4. Tidak ada satu pun siswa atau 0\% meraih kategori kurang sekali yaitu dengan nilai 3. Tidak ada satu pun siswa atau 0\% meraih kategori buruk yaitu dengan nilai 2 dan kategori buruk sekali yaitu dengan nilai I. Pada tes siklus I ini, hasil tes kemampuan menulis puisi 1 menunjukan kategori "hampir cukup". Hal ini terlihat dari rata-rata nilai yang mencapai 5,3 dan belum memenuhi standar ketuntasan belajar mengajar, yaitu sebesar 8,00. Hal ini disebabkan oleh: (1) siswa belum mampu menggunakan majas dalam menulis puisi dan sesuai dengan kriteria yang di nilai (2) Siswa tidak termotivasi dan kurang tertarik mengikuti pelajaran menulis puisi, (3) judul yang di pilih oleh siswa belum sesuai dengan isi puisi, dan (4) siswa masih belum mampu meningkatkan imajinasi dalam menulis puisi dan kurang termotivasi dalam mengikuti pelajaran dikarenakan proses pembelajaran yang kurang inovatif dari guru. 


\section{Kemampuan Menulis Puisi Siswa Sesudah Menggunakan Media Film Pendek Karya Eka Gustiwana}

Hal ini terbukti dari hasil penelitian yang menunjukkan nilai siswa dalam menulis puisi mengalami peningkatan. Peningkatan nilai yang diperoleh siswa disebabkan oleh media film pendek karya Eka Gustiawana. Dilihat dari hasil rata-rata siswa pada pre-test mencapai 64,5 dengan kategori cukup. Sedangkan hasil post-test nilai rata-rata menjadi 83,16 termasuk kategori baik. Hal ini membuktikan adanya peningkatan yang signifikan dari tes awal (pre-test).

Hal ini dapat dilihat dari peningkatan setiap aspek penilaian puisi. Pada aspek tema, sebelum dan sesudah menggunakan media film pendek mendapatkan nilai 20. Pada aspek amanat, sebelum menggunakan media film pendek mendapatkan nilai 19,66, sedangkan sesudah menggunakan media film pendek mendapatkan nilai 20. Kemudian pada aspek diksi, sebelum menggunakan media film pendek mendapatkan nilai 9,33 sementara sesudah menggunakan media film pendek mendapatkan nilai 16,66. Pada aspek gaya bahasa, sebelum menggunakan media film pendek mendapatkan nilai 7,5, sedangkan sesudah menggunakan media film pendek mendapatkan nilai 14,66. Kemudian pada aspek rima, sebelum menggunakan media film pendek mendapatkan nilai 8 , sedangkan sesudah menggunakan media film pendek mendapatkan nilai 11,53. Dapat dilihat bahwa kemampuan menulis puisi siswa pada setiap aspek mengalami peningkatan cukup signifikan setelah menggunakan media film pendek.

Meningkatnya kemampuan dalam menulis puisi juga didukung dengan hasil penelitianSuhatman Jaya, dkk (2013) menyatakanada peningkatan ketuntasan belajar siswa sebanyak $36,7 \%$. Siswa yang tidak tuntas berkurang pada siklus II. Pada siklus I siswa yang tidak tuntas mencapai 13 orang (43,3\%), maka pada siklus II berkurang menjadi 2 orang $(6,7 \%)$. Hasil belajar siswa mengalami peningkatan, dilihat dari rata-rata nilai siswa pada siklus I 69,33 menjadi 82,6 pada siklus II. Dengan demikian, dapat dipahami bahwa terdapat peningkatan yang signifikan hasil keterampilan menulis puisi siswa melalui penggunaan media gambar, yaitu 59,67 pada prasiklus meningkat menjadi 69,33 pada siklus I, dan pada siklus II meningkat menjadi 82,6. Selanjutnya, dapat dipahami bahwa penggunaan media gambar dalam pembelajaran menulis puisi dapat meningkatkan hasil belajar siswa. 
Hal ini sesuai dengan hasil yang diharapkan yaitu meningkatkan hasil belajar siswa dan juga mencapai KKM yang sudah ditetapkan sekolah tersebut. Media film pendek karaya Eka Gustiwana merupakan sebuah media pembelajaran yang dpaat membantu siswa dalam mengembangkan ide dan gagasannya dalam belajar.

Hamalik (dalam Arsyad, 2011:25). Berpendapat bahwa pemakaian media pembelajaran dalam proses belajar mengajar dapat membangkitkan keinginan dan minat yang baru, membangkitkan motivasi, dan rangsangan kegiatan belajar, dan bahkan membawa pengaruh-pengaruh psikologi terhadap siswa. Sependapat dengan hal tersebut, Haryoko (2009) menyatakan bahwa salah satu media yang digunakan dalam pembelajaran dan diyakini dapat meningkatkan animo dakam mengikuti pembelajaran adalah media audio-visual (termasuk film pendek).

Selain itu, media film pendek juga dapat membangkitkan motivasi dan minat siswa untuk berani berperan aktif dalam belajar serta mampu menuliskan apa yang mereka lihat dari film pendek tersebut dan kemudian menjadikannya sebuah puisi yang baik.

Dengan demikian jelas bahwa media film pendek karya Eka Gustiwana ini adalah media pembelajaran yang efektif yang dapat digunakan guru untuk merangsang dan mengembangkan kemampuan siswa dalam menulis puisi. Dengan penggunaan ini daam proses pemebelajaran, guru dapat meningkatkan hasil belajar siswa. Hal tersebut terbukti dari hasil penelitian dan data yang diperoleh.

\section{Pengaruh Media Film Pendek Karya Eka Gustiwana Terhadap Kemampuan Menulis Puisi Siswa Kelas X SMA Free Methodist Medan.}

Sebagaimana disajikan pada hasil penelitian yang menunjukkan nilai rata-rata untuk kemampuan menulis puisi siswa pada tahap sebelum penggunaan medadia film pendek, tergolong pada kategori cukup dengan nilai rata-rata 64,5 dibandingkan dengan tahap setelah penggunaan media film pendek yang berkategori baik dengan nilai rata-rata 83,16. Sehingga dari data tersebut dapat dikemukakan bahwa media film pendek berpengaruh daam meningkatkan kemampuan menulis puisi. 
Hal ini sesuai dengan hasil yang diharapkan yaitu meningkatkan hasil belajar siswa dan juga mencapai KKM yang sudah ditetapkan sekolah tersebut. Media film pendek karaya Eka Gustiwana merupakan sebuah media pembelajaran yang dpaat membantu siswa dalam mengembangkan ide dan gagasannya dalam belajar.

Selain itu, media film pendek juga dapat membangkitkan motivasi dan minat siswa untuk berani berperan aktif dalam belajar serta mampu menuliskan apa yang mereka lihat dari film pendek tersebut dan kemudian menjadikannya sebuah puisi yang baik.

Berdasarkan hasil penelitian, data sebelum dan sesudah menggunakan media film pendek karya Eka Gustiwana berdistribusi normal. Hal tersebut dapat dilihat dari uji normalitas data sebelum dan sesudah menggunakan media film pendek. Dari data homogenitas juga terbukti bahwa sampel penelitian ini berasal dari populasi yang homogen.Kemudian pengujian hipotesis yang dilakukan diperoleh $t_{0}>t_{\text {tabel}}$, yaitu 9,692>2.04. Hal ini membuktikan bahwa .hipotesis alternatif (Ha) diterima. Dengan demikian penggunaan media film pendek karya Eka Gustiwana ini berpengaruh secara signifikan terhadap kemampuan menulis puisi siswa kelas X SMA Free Methodist Medan Tahun Pembelajaran 2017/2018.

\section{SIMPULAN DAN SARAN}

\section{Simpulan}

Berdasarkan hasil penelitian yang telah diuraikan pada bab IV, dapat disimpulkan sebagai berikut.

1. Kemampuan siswa kelas X SMA Free Methodist Medan Tahun Pembelajaran 2017/2018 dalam menulis puisis sebelum menggunakan media film pendek karya Eka Gustiwana tergolong cukup dengan nilai rata-rata yang diperoleh 64,5 termasuk dalam kategori cukup.

2. Kemampuan siswa kelas X SMA Free Methodist Medan Tahun Pembelajaran 2017/2018 dalam menulis puisi sesudah menggunakan media film pendek karya Eka 
Gustiwana tergolong baik dengan nilai rata-rata yang diperoleh 83,16 termasuk dalam kategori baik

3. Terdapat pengaruh media film pendek karya Eka Gustiwana terhadap kemampuan menulis puisi siswa X SMA Free Methodist Medan Tahun Pembelajaran 2017/2018. Dapat dilihat dari hasil penelitian yang dilakukan yaitu hasil post-tets serta hasul uji " $\mathrm{t}$ " $\mathrm{t}_{\mathrm{o}}>\mathrm{t}_{\text {tabel}}$, yaitu 9,692>2.04, maka hipotesis nihil (H0) ditolak dan hipotesis alternatif (Ha) diterima.

\section{Saran}

Berdasarkan kesimpulan di atas, maka sebagai tindak lanjut penelitian ini perlu diungkapkan saran-saran berikut.

\section{Untuk Sekolah}

a. Kemampuan menulis puisi perlu ditingkatkan lagi. Untuk meningkatkannya diperlukan suatu media pembelajaran yang dapat meningkatkan keinginan dan motivasi siswa dalam menulis puisi.

b. Salah satu media pembelajaran yang dapat digunakan untuk meningkatkan kemampuan menulis puisi siswa adalah media film pendek karya Eka Gustiwanakarena dengan media pembelajaran ini, kemampuan menulis siswa khususnya dalam menulis puisi terbukti meningkat.

\section{Untuk Guru}

a. Guru diharapkan untuk lebih kreatif dalam melaksanakan pembelajaran di sekolah dengan mengikuti perkembangan zaman dan memperhatikan kebutuhan, keinginan, dan kemampuan siswa. Misalnya dengan menerapkan metode-metode yang baru atau yang menarik dan inovatif, yang dapat membangkitkan antusias siswa.

b. Guru diharapkan untuk lebih produktif dalam meningkatkan kemampuan siswa dengan memberikan latihan secara berkesinambungan

c. Gurusudah seyogyanya memperhatikan dan memilih media yang tepat dalam sebuah pembelajaran. Kurang tepatnya media yang digunakan dalam pembelajaran berpengaruh terhadap hasil belajar siswa. Oleh karena itu, perlu adanya referensi mengenai berbagai media pembelajaran yang dapat digunakan dalam mengajarkan materi. 


\section{Untuk Siswa}

Penelitian ini dapat membantu siswa dalam mengatasi kesulitan yang dihadapi dalam pembelajaran menulis puisi bebas.Selain itu, dengan penelitian ini, diharapkan siswa dapat menambah wawasan yang memadai mengenai menulis puisi bebas.

4. Untuk Peneliti

Perlu dilakukan penelitian lanjut oleh peneliti lain guna memberi masukan yang konstruktif bagi dunia pendidikan khususnya dalam meningkatkan kemampuan siswa menulis puisi.

\section{DAFTAR PUSTAKA}

Arikunto, Suharsimi. 2006. Prosedur Penelitian Suatu Pendekatan Praktis. Jakarta: Rineka Cipta

Arsyad, Azhar. 2014. Media Pembelajaran. Jakarta: Raja Grafindo Persada.

Sugiyono.2010. Metode Penelitian Kuantitatif dan Kualitatif.Bandung : Alfabeta

Suriamiharja, dkk. 1996. Petunjuk Praktis Menulis. Jakarta : Departemen Pendidikan dan Kebudayaan.

Susilana, R dan Riyani C. 2009.Media Pembelajaran.Bandung: CV Wacana Prima

Tarigan, Henry Guntur. 1986. Menulis Sebagai Suatu Keterampilan Berbahasa. Bandung: Angkasa Raya.

.2008. Menulis Sebagai Suatu Keterampilan Berbahasa. Bandung: Angkasa Raya.

Waluyo, Herman. 2002. Apresiasi Puisi. Jakarta: Gramedia Pustaka Umum.

Rizky, Mertyn., dkk. Film Pendek Sebagai Media Untuk Meningkatkan Pembelajaran Menulis Cerpen $\quad$ berdasarkan Pengalaman Orang Lain Di Kelas X-4 Sman 02 Batu. Malang: Universitas Negeri Malang

Suhatman Jaya . 2013. Jurnal:Peningkatan Keterampilan Menulis Puisi Melalui Media Gambar Siswa Kelas X.1 SMA Negeri 2 Kota Sungai Penuh.Padang: Universitas Negeri Padang 